\title{
Intestinal parasites and diarrhoea in a childrens hospital in Sri Lanka
}

Jennifer Perera ${ }^{1}$, Innocent Jayawardene', Lalitha Mendis ${ }^{1}$ and Kamalika Abeyratne ${ }^{2}$

The Ceylon Journal of Medical Science 1999; 42: 7-12

\section{Summary}

The objective of the study was to determine the prevalence of parasitic infestations in children with diarrhoea and its effect on the course of the diarrhoea. A case control study was carried out at the Lady Ridgeway Hospital, Colombo, Sri Lanka.

The study population consisted of 940 children with acute diarrhoea and 260 children admitted for conditions other than diarrhoea. The first sample of stool was examined for bacteria (Salmonella spp, Shigella spp, Aeromonas spp, Campylobacter spp, Vibrio cholerae, Vibrio parahaemolyticus and Enteropathogenic E.coli), viruses (rotavirus and adenoviruses) and parasites ( $E n$ tamoeba histolytica, Cryptosporidium spp, Giardia lamblia, Ascaris lumbricoides, Trichuris trichiura, Necator americanus and Enterobius vermicularis) using standard techniques.

Among children with diarrhoea, $9.3 \%$ had parasitic infections and $6.5 \%$ were infected with parasites which are known to cause diarrhoea. In $4.5 \%$, the parasite was the only pathogen that was detected. Malnutrition was found to-be more prevalent in children whose diarrhoeal illness was associated with parasites especially in children who had $G$. lamblia and T.trichiura infections. When Salmonella and rotavirus diarrhoea was associated with 'nondiarrhoeal' parasitic agents more severe symptoms were observed and the duration of the illness was prolonged in rotavirus diarrhoea.

The results show that parasites may alter the course of acute diarrhoea due to bacteria and viruses. Therefore parasitological investigations should complement bacterial and viral diagnosis in patients with diarrhoea as specific therapy could be instituted.

\section{Introduction}

Diarrhoea is an important cause of morbidity and mortality in most developing countries and is the second commonest cause of morbidity among Sri Lankan children. Acute watery diarrhoea caused by bacteria and viruses can lead to death or dehydration. In contrast, intestinal parasitic infections associated with diarrhoea are less immediately dangerous, but the part they play in chronic diarrhoea and malnutrition is well documented $(1,2,3)$.

The protozoans Entamoeba histolytica, Giardia lamblia and Cryptosporidium species and the helminth, Trichuris trichiura are causally associated with diarrhoea. These organisms interact with the intestinal mucosa in several ways. Pathogenic amoebae can cause tissue damage through contact cytotoxicity and by production of cytotoxins (4). Diarrhoea caused by T.trichiura is attributable to mechanical irritation and mucosal damage. Many of these parasites cause loss of body salts and minerals, but some (eg. E. histolytica and $T$. trichiura) cause loss of blood and proteins from damaged intestinal mucosa.

The influence of parasites on episodes of childhood diarrhoea has not been examined in Sri Lanka. We report here our observations on the interactions and effects of parasitic infestation in children presenting with diarrhoea.

\section{Department of Microbiology, Faculty of Medicine, University of Colombo.}

2. Lady Ridgeway Childrens Hospital, Colombo. 


\section{Material and Methods}

We examined 940 consecutive faecal specimens from children aged one month to twelve years who were admitted from August 1987 to April 1989 to Ward number 2 of Lady Ridgeway Childrens Hospital with acute diarrhoea and 260 age matched controls admitted for conditions other than diarrhoea.

The first sample of stool obtained after hospitalisation was examined for the presence of bacterial, viral and parasitic agents. Trophozoites and cysts of E. histolytica and G. lamblia and ova of Ascaris lumbricoides. T. trichiura, Necator americanus and Enterobius vermicularis were detected in fresh stools by observing unstained direct mounts and iodine stained mounts. Cryptosporidium oocysts were detected by staining faecal smears by a modified Ziehl-Neelsen technique (5).

Rotavirus was detected by Enzyme Immunoassay (EIA) (DAKOPATTS, Denmark) and enteric adenoviruses, by latex agglutination (Adenolexorion Diagnostic, Finland).

The isolation and identification of Salmonella species, Shigella species, Vibrio species, Aeromonas species and Enteropathogenic E.coli (EPEC) were carried out using standard laboratory techniques (6). Cold enrichment followed by culture on MacConkey agar was used for the isolation of Yersinia enterocolitica. Labile toxin (LT) of Enterotoxigenic E.coli (ETEC) was detected by EIA (7). Stable toxin (ST) of ETEC was detected by DNA hybridization using an enzyme labelled probe SNAPR (Dupont - NEN research product) (8).

Each patient's clinical history, examination, nutritional status treatment and response to therapy was recorded on a clinical history sheet by the Senior House Officer. The nutritional status was determined by using the weight relative to age. Data were analysed using the standard error of difference of proportions.

\section{Results and Discussion}

Of 940 cases $87(9.3 \%)$ had parasitic infection which was significantly higher than among controls. Only 11 of $260(4.3 \%)$ controls had parasites in their stools. Sixty one of the 87 cases $(70.1 \%$ ) had parsites which are known to cause diarrhoea among which Cryptosporidium species and $T$. trichiura were the predominant parasites (Table 1). In 39 of these 87 patients (44.8\%), the parasite was the only pathogen that was detected. In 48 patients parasites were found concomitantly with bacterial and viral pathogens.

Cryptosporidium was the commonest parasite detected indicating that it would be good practice to seek this pathogen routinely in stools of children with diarrhoea (Table 1). This would prevent unnecessary treatment with antibiotics. In fact it has been reported that treatment with antibiotics prolonged the duration of diarrhoea due to Cryptosporidium (9).

Children affected with Cryptosporidium and G.lamblia were younger than children with worm infestations. However this finding was not statistically significant (Table 2). Malnutrition was observed in a significantly higher proportion of children infected with G.lamblia and T.trichiura $(p<0.05)$ than those who were infected with other parasites (Table 2). Diarrhoea associated with parasites was seen significantly more in malnourished than in well nourished children (Table 3).

In the present series $28.7 \%$ and $9.7 \%$ of children with Salmonella and rotavirus diarrhoea respectively had blood and mucus stools (Table 4). However in instances where rotavirus infection was associated with parasitic infections blood and mucus stools were observed in $50 \%$ of cases. Similarly, when Salmonella diarrhoea was associated with parasitic infestations blood and mucus stools occurred in $87.5 \%$ of cases. Both these differences were statistically significant, $p<0.05$. (Table 4). Therefore the presence of parasites seem to produce more severe disease in children with diarrhoea. Table 5 shows the associated parasitic infections and the nature of the stool in diarrhoea caused by Salmonella species and rotavirus. 
Although it is documented that Cryptosporidium infection caused either a watery or mucoid diarrhoea (5), in the present study blood and mucus stools was observed when Cryptosporidium was associated with bacterial or viral pathogens. Five out of 9 cases presented with blood and mucus diarrhoea (Table 5).

In this study 10 cases were observed with only
T.trichiura infection among which 5 or $50 \%$ had blood and mucus stools. Six patients had either Salmonella or rotavirus in addition to T.trichiura infection, and all 6 had blood and mucus stools (Table 5). T.trichiura infections lead to blood and mucus stools only when the worm load is very heavy (10). We are unable to comment on the worm load, but, none of these children had rectal prolapse which is a feature of heavy worm load.

Table 1

Prevalence of intestinal parasites in children presenting with acute diarrhoea $(n=940)$ and control group $(n=260)$

\begin{tabular}{|c|c|c|c|c|}
\hline \multirow[t]{2}{*}{ Parasite } & \multicolumn{2}{|c|}{$\begin{array}{l}\text { Parasites among cases } \\
(n=87)\end{array}$} & \multicolumn{2}{|c|}{$\begin{array}{l}\text { Parasites among controls } \\
(\mathrm{n}=11)\end{array}$} \\
\hline & Number & $\%$ & Number & $\%$ \\
\hline Cryptosporidium & 26 & (2.7) & 1 & $(0.4)$ \\
\hline Trichuris trichiura & 21 & $(2.2)$ & 2 & $(0.7)$ \\
\hline Giardia lamblia & 9 & $(0.9)$ & - & \\
\hline Entamoeba histolytica & 5 & $(0.5)$ & - & \\
\hline Trichomonas hominis & 1 & $(0.1)$ & - & \\
\hline Ascaris lumbricoides & 22 & (2.3) & 8 & $(3.0)$ \\
\hline Necator americanus & 3 & $(0.3)$ & - & \\
\hline Total & $87^{*}$ & (9.3) & $11^{*}$ & $(4.2)$ \\
\hline
\end{tabular}

*Parasite infection was significantly higher among cases compared to controls $(\mathrm{p}<0.001)$ 
Table 2

Mean age and nutritional status of children with diarrhoea in whom the parasite was the only pathogen detected $(n=39)$

\begin{tabular}{lllll}
\hline Parasite & $\begin{array}{l}\text { Number of } \\
\text { Patients }\end{array}$ & $\begin{array}{l}\text { Mean age } \\
\text { (Years) }\end{array}$ & \multicolumn{2}{c}{$\begin{array}{l}\text { Nutritional status } \\
\text { PCM3* }\end{array}$} \\
\hline Cryptosporidium & 17 & 2.20 & $1 / 15$ & $(7)$ \\
T.trichiura & 12 & 5.13 & $6 / 10^{*}$ & $(60)$ \\
G.lamblia & 5 & 1.80 & $3 / 5^{*}$ & $(60)$ \\
A.lumbricoides & 5 & 2.00 & $1 / 5$ & $(20)$ \\
& & & & \\
\hline
\end{tabular}

- According to Gomez classification

* Malnutrition was observed significantly more in children infected with T. trichiura and G. lamblia compared to other parasites $(\mathrm{p}<0.05)$

Table 3

Nutritional status (Gomez classification) of children with diarrhoea in relation to the pathogen detected

\begin{tabular}{|c|c|c|c|c|}
\hline \multirow[t]{3}{*}{ Organism } & \multicolumn{4}{|c|}{ Nutritional status } \\
\hline & \multicolumn{2}{|c|}{ Normal / PCM1 } & \multicolumn{2}{|c|}{ PCM2 / PCM3 } \\
\hline & Number & $(\%)$ & Number & $(\%)$ \\
\hline Bacteria + Virus & 425 & $(55.4)$ & 342 & $(44.6)$ \\
\hline Parasites & 18 & $(46.2)$ & 21 & $(53.8)^{*}$ \\
\hline Bacteria + Virus + parasites & 17 & $(35.5)$ & 31 & $\left(64.5^{*}\right)$ \\
\hline
\end{tabular}

* Children in PCM2 \PCM3 groups had more parasite associated diarrhoea compared to children in normal / PCM1 group $(p<0.01)$ 
Table 4

A comparison of stools in cases with Salmonella and rotavirus infection alone versus those with Salmonella or rotavirus infection combined with a parasitic infection

\begin{tabular}{lccc}
\hline Organism & $\begin{array}{l}\text { Number of } \\
\text { Infections }\end{array}$ & $\begin{array}{l}\text { Nature of stool } \\
\text { blood \& } \\
\text { mucus (\%) }\end{array}$ & $\begin{array}{l}\text { watery \& } \\
\text { mucoid (\%) }\end{array}$ \\
\hline $\begin{array}{l}\text { Salmonella } \\
\begin{array}{l}\text { Salmonella } \\
\text { Parasites }\end{array}\end{array}$ & 63 & $19(30.1)$ & $44(69.8)$ \\
$\begin{array}{l}\text { Rotavirus } \\
\text { Rotavirus + } \\
\text { Parasites }\end{array}$ & 314 & $\cdot$ & $\cdot$ \\
\hline
\end{tabular}

Salmonella in association with parasites* and rotavirus in association with parasites" result in a significantly higher number of patients with blood and mucus stools when compared to diarrhoea caused by Salmonella or rotavirus alone ( ${ }^{*}$ and $" \mathrm{p}<0.05$ ).

Table 5

Nature of stool when parasites were associated with either a bacterial or viral pathogen

\begin{tabular}{llll}
\hline $\begin{array}{l}\text { Parasite } \\
\text { + pathogen }\end{array}$ & $\begin{array}{l}\text { Number of } \\
\text { infections } \\
\text { studied }\end{array}$ & blood \& mucus & Pattern of diarchoea \\
& & & watery \& mucoid
\end{tabular}

A.lumbricoides +

Rotavirus

4

2

2

Cryptosporidium +

Rotavirus

T.trichiura +

Rotavirus

A.lumbricoides +

Salmonella spp

T.trichiura +

Salmonella spp

N. americanus +

Salmonella spp

Cryptosporidium +

Salmonella spp

3

2 1

Total number

22

14 8 
The average duration of diarrhoea due to rotavirus was prolonged to over 14 days when associated with roundworm, whereas the mean duration of uncomplicated rotavirus diarrhoea is about 8 days (11). This may suggest that concomitant roundworm infestation predisposes to a more prolonged and severe clinical illness. However the stools were not examined for all known bacterial and viral pathogens ie, Entero-haemorrhagic and Entero-invasive E coli (which give rise to blood and mucus diarrhoea), Norwalk virus etc, which is a limitation in the study.

From the above results and discussion it appears that parasites alter the course of an acute diarrhoea. This may be due to direct action of the parasite or parasite products on the intestinal mucosa or due to indirect factors such as malnutrition and malabsorption. Further studies should be carried out to determine the pathogenic mechanisms exerted by parasites on the intestinal mucosa. Furthermore multiple aetiological agents may be responsible for severe and prolonged diarrhoea and should be investigated for, when facilities are available.

In most laboratories in Sri Lanka, diarrhoea stools are often examined for bacterial pathogens and sometimes for amoebae when there is blood and mucus. A simple faecal smear is adequate for screening for parasites. We recommend that in developing countries parasitological investigation should complement bacterial and viral diagnosis in patients presenting with diarrhoea illness because specific therapy instituted against the parasite may alter the course of that diarrhoeal episode as well as future episodes.

\section{Acknowledgements}

Financial support provided by UNICEF Sri Lanka (Grant No AP/3/ii/87/148/UNICEF), technical assistance provided by $\mathrm{Mr} \mathrm{S}$. Gamage and secretarial services of Ms S. Hendalage are gratefully acknowledged.

\section{References}

1. Brasitus TA. Parasites and malabsorption. Clinics in Gastroenterology 1983; 12: 495-508.

2. Tripathey K, Duque E, Bolanos E, Lotero $H$, Maoral LG. Malabsorption syndrome in Ascaris. American Journal of Clinical Nutrition 1972; 25: 1276-1281.

3. Ighoboja IS, Ikeh E I, Parasitic agents in child hood diarrhoea and malnutrition. West African Journal of Medicine 1997; 16: 36-9.

4. Tharavanij S. Pathogenesis caused by parasites. Southeast Asian Journal of Tropical Medicine and Public Health 1982; 13: 331-338.

5. Perera J. Cryptosporidium associated childhood diarrhoea in Sri Lanka - A preliminary study. Ceylon Medical Journal 1988; 33: 101-104.

6. Lennette HE, Balows A, Hausler WJ, Shadomy HJ. Manual of Clinical Microbiology 4th Ed. American Society for Microbiology, Washington DC. 1985: 175.

7. Svennerholm A M, Holmgren J. Identification of Escherichia coli heat-labile enterotoxin by means of a ganglioside immunosorbent assay (GM 1 -ELISA) procedure. Current Microbiology 1978; 1: 19-23.

8. Echeverria P, Taylor DN, Seriwatana J. Moe C. Comparative study of synthetic oligonuelcotide and cloned polynucleotide enterotoxin gene probes to identify enterotoxigenic E.coli. Journal of Clinical Microbiology 1987; 25: 106-109.

9. Mathan $M M$, Venkatesan S, George R, Mathew M, Mathan V I. Cryptosporidium and diarrhoea in Southern Indian children. Lancet 1985; ii: 1172-1175.

10. Bundy D A P Epidemiological aspects of Trichuris and trichiuriasis in Carribbean communities. Transactions of the Royal Society of Tropical Medicine and Hygiene 1986; 80: 706-718.

11. Tallets $S$, Mackenzi $C$, Middleton $P$, Kerzner B, Hamilton R. Clinical, laboratory and epidemiologic features of a viral gastroenteritis in infants and Children. Pediatrics 1977; 60: 217-22 